\title{
PENGARUH GLOBALISASI TERHADAP EKSISTENSI KEBUDAYAAN DAERAH
}

\author{
Sa'roni SH,MM
}

\begin{abstract}
Development of technology and culture in the modern era, causes the changes of values in the nation, one is the traditional culture. One of the issue according to this fenomena is the degradation of understanding new gereration to the traditional art which is already estaveted by senior generation in Indonesia.

Most of the young generation prefer to influenced by other culture and civilization which are more trending and universal according to them.

Globalization influences indirectly to the development of Indonesian culture, both negative and positive influence..

One of the positive influence is that the young generations now are literate in foreign language, science and technology also in study and communications. That is why they have the opportunity to gain succesful in their life.

The competitions in globalization era make every specialis should literate in computer and automation application to gain the succesful in their field.
\end{abstract}

Key Words : Globalization, Existency, Rural Culture.

PENDAHULUAN

\section{A. LATAR BELAKANG}

Globalisasi adalah suatu
fenomena khusus dalam peradaban
manusia yang bergerak terus dalam
masyarakat global dan merupakan bagian
dari proses manusia global itu. Kehadiran
teknologi informasi dan teknologi
komunikasi mempercepat akselerasi proses
globalisasi ini. Globalisasi menyentuh
seluruh aspek penting kehidupan.

Globalisasi menciptakan berbagai tantangan dan permasalahan baru yang harus dijawab, dipecahkan dalam upaya memanfaatkan globalisasi untuk kepentingan kehidupan. Globalisasi sendiri merupakan sebuah istilah yang muncul sekitar dua puluh tahun yang lalu, dan mulai begitu populer sebagai ideologi baru sekitar lima atau sepuluh tahun terakhir. Sebagai istilah, globalisasi begitu mudah diterima atau dikenal masyarakat seluruh dunia. Wacana globalisasi sebagai sebuah 
prosesditandai dengan pesatnya perkembangan ilmu pengetahuan dan teknologi sehingga ia mampu mengubah dunia secara mendasar. Globalisasi sering diperbincangkan oleh banyak orang, mulai dari para pakar ekonomi, sampai penjual iklan. Dalam kata globalisasi tersebut mengandung suatu pengertian akan hilangnya satu situasi dimana berbagai pergerakan barang dan jasa antar negara diseluruh dunia dapat bergerak bebas dan terbuka dalam perdagangan. Dan dengan terbukanya satu negara terhadap negara lain, yang masuk bukan hanya barang dan jasa, tetapi juga teknologi, pola konsumsi, pendidikan, nilai budaya, dan lain-lain. Konsep akan globalisasi menurut Robertson (1992), mengacu pada penyempitan dunia secara insentif dan peningkatan kesadaran kita akan dunia, yaitu semakin meningkatnya koneksi global dan pemahaman kita akan koneksi tersebut. Disini penyempitan dunia dapat dipahami dalam konteks institusi modernitas dan intensifikasi kesadaran dunia dapat dipersepsikan refleksif dengan lebih baik secara budaya. Globalisasi memiliki banyak penafsiran dari berbagai sudut pandang. Sebagian orang menafsirkan globalisasi sebagai proses pengecilan dunia atau menjadikan dunia sebagaimana layaknya sebuah perkampungan kecil.

Sebagian lainnya menyebutkan bahwa globalisasi adalah upaya penyatuan masyarakat dunia dari sisi gaya hidup, orientasi, dan budaya. Pengertian lain dari globalisasi seperti yang dikatakan oleh Barker (2004) adalah bahwa globalisasi merupakan koneksi global ekonomi, sosial, budaya dan politik yang semakin mengarah ke berbagai arah di seluruh penjuru dunia dan merasuk ke dalam kesadaran kita. Produksi global atas produk lokal dan lokalisasi produk global. Globalisasi adalah proses dimana berbagai peristiwa, keputusan dan kegiatan di belahan dunia yang satu dapat membawa konsekuensi penting bagi berbagai individu dan masyarakat di belahan dunia yang lain (A.G. Mc. Grew, 1992). Proses perkembangan globalisasi pada awalnya ditandai kemajuan bidang teknologi informasi dan komunikasi. Bidang tersebut merupakan penggerak globalisasi. Dari kemajuan bidang ini kemudian mempengaruhi sektor-sektor lain dalam kehidupan, seperti bidang politik, ekonomi, sosial, budaya dan lain-lain. Contoh sederhana dengan teknologi internet, parabola dan TV, orang di belahan bumi manapun akan dapat mengakses berita dari belahan dunia yang lain secara cepat. Hal ini akan terjadi interaksi antar 
masyarakat dunia secara luas, yang akhirnya akan saling mempengaruhi satu sama lain, terutama pada kebudayaan daerah, seperti kebudayaan gotong royong, menjenguk tetangga sakit dan lain-lain. Globalisasi juga berpengaruh terhadap pemuda dalam kehidupan sehari-hari, seperti budaya berpakaian, gaya rambut dan sebagainya.

\section{B. IDENTIFIKASI MASALAH}

Dalam pengembangannya globalisasi menimbulkan berbagai masalah dalam bidang kebudayaan. Misalnya:

$\checkmark$ Hilangnya budaya asli suatu daerah atau suatu negara

$\checkmark$ Terjadinya erosi nilai-nilai budaya

$\checkmark$ Menurunnya rasa nasionalisme dan patriotisme

$\checkmark$ Hilangnya sifat kekeluargaan dan gotong royong

Kehilangan kepercayaan diri

$\checkmark \quad$ Gaya hidup kebarat-baratan.

\section{RUMUSAN MASALAH}

\section{Adanya globalisasi}

menimbulkan berbagai masalah terhadap eksistensi kebudayaan daerah, salah satunya adalah terjadinya penurunan rasa cinta terhadap kebudayaan yang merupakan jati diri suatu bangsa, erosi nilai-nilai budaya, terjadinya akulturasi budaya yang selanjutnya berkembang menjadi budaya.

\section{TUJUAN}

$\checkmark$ Mengetahui pengaruh globalisasi terhadap eksistensi kebudayaan daerah.

$\checkmark$ Untuk meningkatkan kesadaran remaja untuk menjunjung tinggi kebudayaan bangsa sendiri karena kebudayaan merupakan jati diri bangsa.

\section{BAB II}

KERANGKA TEORITIK DAN RUMUSAN HIPOTESIS

\section{BATASAN ISTILAH}

Dalam pembuatan makalah ini menggunakan istilah-istilah yang sudah simengerti oleh masyarakat banyak, adapun tujuan dari penggunaan istilahistilah tersebut yaitu untuk memudahkan pembaca dalam membaca makalah ini.

\section{SUDUT PANDANG PENDEKATAN}

Sudut pandang yang kami gunakan dalam pembuatan makalah ini yaitu sudut pandang secara sosiologis dan psikologis yaitu pengaruh globalisasi pada 
masyarakat umum dan sikap para pemuda dalam menyikapi pengaruh budaya asing. memunculkan rasa cinta terhadap budaya asing.

\section{KERANGKA BERPIKIR}

Dalam pembuatan makalah ini kami menggunakan pola paragraf dari umum ke khusus, dengan alasan agar pembaca tidak merasa bingung dalam membaca karena dalam membaca dimulai dari hal-hal yang ringan dulu baru meningkat ke hal-hal yang lebih kompleks.

\section{RUMUSAN HIPOTESIS}

Adanya globalisasi yang memiliki dampak positif maupun negative, maka perlu adanya tindak lanjut dalam menyikapi globalisasi tersebut. Adapun tindakan-tindakan yang dapat dilakukan yaitu:

Menambah porsi pengetahuan tentang kebudayaan bangsa di sekolah-sekolah baik mulai dari tingkat SD sampai perguruan tinggi.

Menyeleksi kemunculan globalisasi kebudayaan baru, sehingga budaya yang masuk tidak merugikan dan berdampak negatif.

Mengadakan berbagai pertunjukkan kebudayaan.

Membatasi acara-acara yang dapat

\section{BAB III}

\section{PEMBAHASAN}

\section{A. GLOBALISASI DAN BUDAYA}

Gaung globalisasi, yang sudah mulai terasa sejak akhir abad ke-20, telah membuat masyarakat dunia, termasuk bangsa Indonesia harus bersiap-siap menerima kenyataan masuknya pengaruh luar terhadap seluruh aspek kehidupan bangsa. Salah satu aspek yang terpengaruh adalah kebudayaan. Terkait dengan kebudayaan, kebudayaan dapat diartikan sebagai nilai-nilai (values) yang dianut oleh masyarakat ataupun persepsi yang dimiliki oleh warga masyarakat terhadap berbagai hal. Atau kebudayaan juga dapat didefinisikan sebagai wujudnya, yang mencakup gagasan atau ide, kelakuan dan hasil kelakuan (Koentjaraningrat), dimana hal-hal tersebut terwujud dalam kesenian tradisional kita. Oleh karena itu, nilai-nilai maupun persepsi berkaitan dengan aspekaspek kejiwaan atau psikologis, yaitu apa yang terdapat dalam alam pikiran. Aspekaspek kejiwaan ini menjadi penting artinya apabila disadari, bahwa tingkah laku seseorang sangat dipengaruhi oleh apa yang ada dalam alam pikiran orang yang 
bersangkutan. Sebagai salah satu hasil pemikiran dan penemuan seseorang adalah kesenian, yang merupakan subsistem dari kebudayaan.

\section{Bagi bangsa Indonesia aspek} kebudayaan merupakan salah satu kekuatan bangsa yang memiliki kekayaan nilai yang beragam, termasuk keseniannya. Kesenian rakyat, salah satu bagian dari budaya bangsa Indonesia tidak luput dari pengaruh globalisasi. Globalisasi dalam kebudayaan dapat berkembang dengan cepat, hal ini tentunya dipengaruhi oleh adanya kecepatan dan kemudahan dalam memperoleh akses komunikasi dan berita namun hal ini justru menjadi bumerang tersendiri dan menjadi suatu masalah yang paling krusial atau penting dalam globalisasi, yaitu kenyataan bahwa perkembangan ilmu pengetahuan dikuasai oleh negara-negara maju. Akibatnya, negara-negara berkembang, seperti Indonesia selalu khawatir akan tertinggal dalam arus globalisasi dalam berbagai bidang seperti politik, ekonomi, sosial, budaya, termasuk kesenian kita. Wacana globalisasi sebagai sebuah proses ditandai dengan pesatnya perkembangan ilmu pengetahuan dan teknologi sehingga ia mampu mengubah dunia secara mendasar. Komunikasi dan transportasi internasional telah menghilangkan batas-batas budaya setiap bangsa. Kebudayaan setiap bangsa cenderung mengarah kepada globalisasi dan menjadi peradaban dunia sehingga melibatkan manusia secara menyeluruh. Simon Kemoni, sosiolog asal Kenya mengatakan bahwa globalisasi dalam bentuk yang alami akan meninggikan berbagai budaya dan nilai-nilai budaya. Dalam proses alami ini, setiap bangsa akan berusaha menyesuaikan budaya mereka dengan perkembangan baru sehingga mereka dapat melanjutkan kehidupan dan menghindari kehancuran. Tetapi menurut Simon Kimoni, dalam proses ini negaranegara harus memperkokoh dimensi budaya mereka dan memelihara struktur nilai-nilainya agar tidak dieleminasi oleh budaya asing. Dalam rangka ini, berbagai bangsa haruslah mendapatkan informasi ilmiah yang bermanfaat dan menambah pengalaman mereka. Terkait dengan seni dan budaya, seorang penulis asal Kenya bernama Ngugi Wa Thiong'o menyebutkan bahwa perilaku dunia barat, khususnya Amerika seolah-olah sedang melemparkan bom budaya terhadap rakyat dunia. Mereka berusaha untuk menghancurkan tradisi dan bahasa pribumi sehingga bangsa-bangsa tersebut kebingungan dalam upaya mencari identitas budaya nasionalnya. Penulis Kenya ini meyakini bahwa budaya asing yang berkuasa di 
berbagai bangsa, yang dahulu dipaksakan melalui imperialisme, kini dilakukan dalam bentuk yang lebih luas dengan nama globalisasi.

B. GLOBALISASI

DALAM

KEBUDAYAAN TRADISIONAL DI INDONESIA

Proses saling mempengaruhi adalah gejala yang wajar dalam interaksi antar masyarakat. Melalui interaksi dangan berbagai masyarakat lain, bangsa indonesia ataupun kelompok-kelompok masyarakat yang mendiami nusantara (sebelum Indonesia terbentuk) telah mengalami proses dopengaruhi dan mempengaruhi. Kemampuan berubah merupakan sifat yang penting dalam kebudayaan manusia. Tanpa itu kebudayaan tidak mampu menyesuaikan diri dengan keadaan yang senantiasa berubah. Perubahan yang terjadi saat ini berlangsung begitu cepat. Hanya dalam jangka waktu satu generasi banyak negaranegara berkembang telah berusaha melaksanakan perubahan kebudayaan, padahal di negara-negara maju perubahan demikian berlangsung selama beberapa generasi. Pada hakekatnya bangsa Indonesia, juga bangsa-bangsa lain, berkembang karena adanya pengaruh- pengaruh luar. Kemajuan bisa dihasilkan oleh interaksi dengan pihak luar, hal inlah yang terjadi dalam proses globalisasi. Oleh karena itu, globalissi bukan hanya soal ekonomi namun juga terkait dengan masalah atau isu makna budaya dimana nilai dan makna yang terlekat di dalamnya masih tetap berarti. Masyarakat Indonesia merupakan masyarakat yang majemuk dalam berbagai hal, seperti anekaragam budaya, lingkungan alam, dan wilayah geografis. Keanekaragaman masyarakat Indonesia ini dapat dicerminkan pula dalam berbagai ekspresi kesenian. Dengan perkataan lain, dapat dikatakan pula bahwa berbagai kelompok masyarakat di Indonesia dapat mengembangkan keseniannya yang sangat khas. Kesenian yang dikembangkannya itu menjadi model-model pengetahuan dalam masyarakat.

\section{PERUBAHAN BUDAYA DALAM GLOBALISASI KESENIAN YANG BERTAHAN DAN YANG TERSISIHKAN}

Perubahan budaya yang terjadi di masyarakat tradisional, yakni perubahan 
dari masyarakat tertutup menjadi masyarakat yang lebih terbuka, dari nilainilai yang bersifat homogen menuju pluralisme nilai dan norma sosial merupakan salah satu dampak dari adanya globalisasi. Ilmu pengetahuan dan teknologi telah mengubah dunia secara mendasar. Komunikasi dan sarana transportasi internasional telah menghilangkan batas-batas budaya setiap bangsa. Kebudayaan setiap bangsa cenderung mengarah kepadaglobalisasi dan menjadi peradaban dunia sehingga melibatkan manusia secara menyeluruh. Misalnya saja khusu dalam bidang hiburan massa atau hiburan yang bersifat masal, makna globalisasi itu sudah sedemikian terasa. Sekarang ini setiap hari kita bisa menyimak tayangan film di tv yang bermuara dari negara-negara maju seperti Amerika Serikat, Jepang, Korea, dll melalui stasiun televisi di tanah air. Belum lagi siaran tv internasional yang bisa ditangkap melalui parabola yang kini makin banyak dimiliki masyarakat Indonesia. Sementara itu, keseniankesenian populer lain yang tersaji melalui kaset, VCD, dan DVD yang berasal dari manca negara pun makin marak kehadirannya di tengah-tengah kita. Fakta yang demikian memberikan bukti tentang betapa negara-negara penguasa teknologi mutakhir telah berhasil memegang kendali dalam globalisasi budaya khususnya di negara ketiga. Peristiwa transkultural seperti itu mau tidak mau akan berpengaruh terhadap keberadaan kesenian kita. Padahal kesenian tradisional kita merupakan bagiab dari khasanah kebudayaan nasional yang perlu dijaga kelestariannya. Di saat yang lain dengan teknologi informasi yang semakin canggih seperti saat ini, kita disuguhi oleh banyak alternatif tawaran hiburan dan informasi yang lebih beragam, yang mungkin lebih menarik jika dibandingkan dengan kesenian tradisional kita. Dengan parabola masyarakat bisa menyaksikan berbagai tayangan hiburan yang bersifat mendunia yang berasal dari berbagai belahan bumi. Kondisi yang demikian mau tidak mau membuat semakin tersisihnya kesenian tradisional Indonesia dari kehidupan masyarakat Indonesia yang sarat akan pemaknaan dalam masyarakat Indonesia. Misalnya saja bentuk-bentuk ekspresi kesenian etnis Indonesia, baik yang rekyat maupun istana, selalu berkaitan erat dengan perilaku ritual masyarakat pertanian. Dengan datangnya perubahan sosial yang hadir sebagai akibat proses industrialisasi dan sistem ekonomi pasar, dan globalisasi informasi, maka kesenian kita pun mulai bergeser ke arah kesenian 
yang berdimensi komersial. Keseniankesenian yang bersifat ritual mulai tersingkir dan kehilangan fungsinya. Sekalipun demikian, bukan berarti semua kesenian tradisional kita lenyap begitu saja. Ada berbagai kesenian yang masih menunjukkan eksistensinya, bahkan secara kreatif terus berkembang tanpa harus tertindas proses modernisasi. Pesatnya laju teknologi informasi atau teknologi komunikasi telah menjadi sarana difusi budaya yang ampuh, sekaligus juga alternatif pilihan hiburan yang lebih beragam bagi masyarakat luas. Akibatnya masyarakat tidak tertarik lagi menikmati berbagai seni pertunjukkan tradisional yang sebelumnya akrab dengan kehidupan meraka. Misalnya saja kesenian tradisional wayang orang Bharata, yang terdapat di Gedung Wayang Orang Bharata Jakarta kini tampak sepi seolah-olah tak ada pengunjungnya. Hal ini sangat disayangkan mengingat wayang merupakan salah satu bentuk kesenian tradisional Indonesia yang sarat dan kaya akan pesan-pesan moral, dan merupakan salah satu agen penanaman nilai-nilai moral yang baik, menurut saya. Contoh lainnya adalah kesenian Ludruk yang sampai pada tahun 1980-an masih berjaya di Jawa Timur sekarang ini tengah mengalami "mati suri". Wayang orang dan ludruk merupakan contoh kecil dari mulai terdepaknya kesenian tradisional akibat globalisasi. Bisa jadi fenomena demikian tidak hanya dialami oleh kesenian Jawa tradisional, melainkan juga dalam berbagai ekspresi kesenian tradisional di berbagai tempat di Indonesia. Sekalipun demikian bukan berarti semua kesenian tradisional mati begitu saja dengan merebaknya globalisasi. Di sisi lain, ada beberapa seni pertunjukkan yang tetap eksis tetapi telah mengalami perubahan fungsi. Ada pula kesenian yang mampu beradaptasi dan mentransformasikan diri dengan teknologi komunikasi yang telah menyatu dengan kehidupan masyarakat, misalnya saja kesenian tradisional "Ketoprak" yang dipopulerkan ke layar kaca oleh kelompok Srimulat. Kenyataan di atas menunjukkan kesenian ketoprak sesungguhnya memiliki penggemar tersendiri, terutama ketoprak yang disaji dalam bentuk siaran televisi, bukan ketoprak panggung. Dari segi bentuk pementasan atau penyajian, ketoprak termasuk kesenian tradisional yang telah terbukti mampu beradaptasi dengan perubahan zaman. Selain ketoprak masih ada kesenian lain yang tetap bertahan dan mampu beradaptasi dengan teknologi mutakhir yaitu wayang kulit. Beberapa dalang wayang kulit terkenal seperti Ki Manteb Sudarsono dan Ki 
Anom Suroto tetap diminati masyarakat, baik itu kaset rekaman pementasannya, maupun pertunjukkan secara langsung. Keberanian stasiun televisi Indosiar yang sejak beberapa tahun lalu menayangkan wayang kulit setiap malam minggu cukup sebagai bukti akan besarnya minat masyarakat terhadap salah satu khasanah kebudayaan nasional kita. Bahkan Museum Nasional pun tetap mempertahankan eksistensi dari kesenian tradisional seperti wayang kulit dengan mengadakan pagelaran wayang kulit tiap beberapa bulan sekali dan pagelaran musik gamelan tiap satu minggu atau satu bulan sekali yang diadakan di aula Kertarajasa, Museum Nasional.

\section{PENGARUH GLOBALISASI TERHADAP BUDAYA BANGSA}

Arus globalisasi saat ini telah menimbulkan pengaruh terhadap perkembangan budaya bangsa Indonesia. Derasnya arus informasi dan telekomunikasi ternyata menimbulkan sebuah kecenderungan yang mengarah terhadap memudarnya nilai-nilai pelestarian budaya. Perkembangan 3T (Transportasi, Telekomunikasi, dan Teknologi) mengakibatkan berkurangnya keinginan untuk melestarikan budaya negeri sendiri.

Budaya Indonesia yang dulunya ramah-tamah, gotong-royong dan sopan berganti dengan budaya barat, misalnya pergaulan bebas. Di Tapanuli (Sumatera Utara) misalnya, dua puluh tahun yang lalu, anak-anak remajanya masih banyak yang berminat untuk belajar tari tor-tor dan tagading (alat musik batak). Hampir setiap minggu dan dalam acara ritual kehidupan, remaja di sana selalu diundang pentas sebagai hiburan budaya yang meriah. Saat ini, ketika teknologi semakin maju, ironisnya kebudayaan-kebudayaan daerah tersebut semakin lenyap di masyarakat, bahkan hanya dapat disaksikan di televisi dan Taman Mini Indonesia Indah (TMII). Padahal kebudayaan-kebudayaan daerah tersebut, bila dikelola dengan baik selain dapat menjadi pariwisata budaya yang menghasilkan pendapatan untuk pemerintah baik pusat maupun daerah, juga dapat menjadi lahan pekerjaan yang menjanjikan bagi masyarakat sekitarnya. Hal lain yang merupakan pengaruh globalisasi dalah dalam pemakaian Bahasa Indonesia yang baik dan benar (bahasa juga salah satu budaya bangsa). Sudah lazim di Indonesia untuk menyebut orang kedua tunggal dengan Bapak, Ibu, $\mathrm{Bu}$, Saudara, Anda dibandingkan dengan kau atau kamu sebagai pertimbangan nilai rasa. 
Sekarang ada kecenderungan di kalangan anak muda yang lebih suka menggunakan bahasa Indonesia dialek Jakarta seperti penyebutan kata gue (saya) dan lu (kamu).

Selain itu kita sering dengar anak muda menggunakan bahasa Indonesia dengan dicampur-campur bahasa inggris seperti Ok, No problem dan Yes, bahkan kata-kata makian (umpatan) sekalipun yang sering kita dengar di film-film barat, sering diucapkan dalam kehidupan sehari-hari. Kata-kata ini disebarkan melalui media TV dalam film-film, iklan dan sinetron bersamaan dengan disebarkannya gaya hidup dan fashion. Gaya berpakaian remaja Indonesia yang dulunya menjunjung tinggi norma kesopanan telah berubah mengikuti perkembangan jaman. Ada kecenderungan bagi remaja putri di kota-kota besar memakai pakaian minim dan ketat yang memamerkan bagian tubuh tertentu. Budaya berpakaian minim ini dianut dari film-film dan majalah-majalah luar negeri yang ditransformasikan ke dalam sinetron-sinetron Indonesia. Derasnya arus informasi, yang juga ditandai dengan hadirnya internet, turut serta 'menyumbang' bagi perubahan cara berpakaian. Pakaian mini dan ketat telah menjadi trend dilingkungan anak muda. Salah satu keberhasilan penyebaran kebudayaan barat ialah meluasnya anggapan bahwa ilmu dan teknologi yang berkembang di barat merupakan suatau yang universal. Masuknya budaya barat (dalam kemasan ilmu dan teknologi) diterima dengan 'baik'. Pada sisi inilah globalisasi telah merasuki berbagai sistem nilai sosial dan budaya Timur (termasuk Indonesia) sehingga terbuka pula konflik nilai antara teknologi dan nilai-nilai ketimuran.

E. TINDAKAN YANG MENDORONG TIMBULNYA GLOBALISASI KEBUDAYAAN DAN CARA MENGANTISIPASI ADANYA GLOBALISASI KEBUDAYAAN

Peran kebijaksanaan pemerintah yang lebih mengarah kepada pertimbangan-pertimbangan ekonomi daripada kultural atau budaya dapat dikatakan merugikan suatu perkembangan kebudayaan. Jennifer Lindsay (1995) dalam bukunya yang berjudul 'Cultural Policy and the Performing Arts In SouthEast Asia', mengungkapkan kebijakan kultural di Asia Tenggara saat ini secara efektif mengubah dan merusak seni-seni pertunjukkan tradisional, baik melalui campur tangan, penanganan yang berlebihan, kebijakan-kebijakan tanpa arah, dan tidak ada perhatian yang diberikan pemerintah kepada kebijakan 
kultural atau konteks kultural. Dalam pengamatan yang lebih sempit dapat kita melihat tingkah laku aparat pemerintah dalam menangani perkembangan kesenian rakyat, dimana banyaknya campur tangan dalam menentukan objek dan berusaha merubah agar sesuai dengan tuntutan pembangunan. Dalam kondisi seperti ini arti dari kesenian rakyat itu sendiri menjadi hambar dan tidak ada rasa seninya lagi. Melihat kecenderungan tersebut, aparat pemerintah telah menjadikan para seniman dipandang sebagai objek pembangunan dan diminta untuk menyesuaikan diri dengan tuntutan simbol-simbol pembangunan. Hal ini tentu saja mengabaikan masalah pemeliharaan dan pengembangan kesenian secara murni, dalam arti benar-benar didukung oleh nilai seni yang mendalam dan bukan sekedar hanya dijadikan model saja dalam pembangunan. Dengan demikian, kesenian rakyat semakin lama tidak dapat mempunyai ruang yang cukup memadai untuk perkembangan secara alami atau natural, karena itu, secara tidak langsung kesenian rakyat akhirnya menjadi sangat tergantung oleh model-model pembangunan yang cenderung lebih modern dan rasional. Sebagai contoh dari permasalahan ini dapat kita lihat, misalnya kesenian asli daerah Betawi yaitu tari cokek, tari lenong, dan sebagainya sudah siatur dan disesuaikan oleh aparat pemerintah untuk memenuhi tuntutan dan tujuan kebijakan-kebijakan politik pemerintah. Aparat pemerintah di sini turut mengatur secara normatif, sehingga kesenian Betawi tersebut tidak lagi terlihat keasliannya dan cenderung dapat membosankan. Untuk mengantisipasi halhal yang tidak dikehendaki terhadap keaslian dan perkembangan yang murni bagi kesenian rakyat tersebut, maka pemerintah perlu mengembalikan fungsi pemerintah sebagai pelindung dan pengayom kesenian-kesenian tradisional tanpa harus turut campur dalam proses estetikanya.

Memang diakui bahwa kesenian rakyat saat ini membutuhkan dana dan bantuan pemerintah sehingga sulit untuk menghindari keterlibatan pemerintah dan bagi para seniman rakyat ini merupakan sesuatu yang sulit pula membuat keputusan sendiri untuk sesuai dengan keaslian (originalitas) yang diingingnkan para seniman rakyat tersebut. Oleh karena itu pemerintah harus 'melakoni' dengan benar-benar peranannya sebagai pengayom yang melindungi keaslian dan perkembangan secara estetis kesenian rakyat tersebut tanpa harus merubah dan menyesuaikan dengan kebijakan-kebijakan 
politik. Globalisasi informasi dan budaya yang terjadi menjelang millenium baru seperti saat ini adalah sesuatu yabf tak dapat dielakkan. Kita harus beradaptasi dengannya karena banyak manfaat yang bisa diperoleh. Harus diakui bahwa teknologi komunikasi sebagai salah satu produk dari modernisasi bermanfaat besar bagi terciptanya dialog dan demokratisasi budaya secara masal dan merata. Globalisasi mempunyai dampak yang besar terhadap budaya. Kontak budaya melalui media massa menyadarkan dan memberikan informasi tentang keberadaan nilai-nilai budaya lain yang berbeda dari yang dimiliki dan dikenal selama ini. Kontak budaya ini memberikan masukkan yang penting bagi perubahan-perubahan dan pengembangan-pengembangan nilainilai dan persepsi di kalangan masyarakat yang terlibat dalam proses ini. Kesenian bangsa Indonesia yang memiliki kekuatan etnis dari berbagai macam daerah juga tidak dapat lepas dari pengaruh kontak budaya ini. Sehingga untuk melakukan penyesuaian-penyesuaian terhadap perubahan-perubahan diperlukan pengembangan-pengembangan yang bersifat global namun tetap bercirikan kekuatan lokal atau etnis. Globalisasi budaya yang begitu pesat harus diantisipasi dengan memperkuat identitas kebudayaan nasional. Berbagai kesenian tradisional yang sesungguhnya menjadi aset kekayaan kebudayaan nasional jangan sampai hanya menjadi alat atau slogan para pemegang kebijaksanaan, khususnya pemerintah, dalam rangka keperluan turisme, politik, dan sebagainya. Selama ini pembinaan dan pengembangan kesenian tradisional yang dilakukan lembaga pemerintah masih sebatas pada unsur formalitas belaka, tanpa menyentuh esensi kehidupan kesenian yang bersangkutan. Akibatnya, kesenian tradisional tersebut bukannya berkembang dan lestari, namun justru semakin dijauhi masyarakat. Dengan demikian, tantangan yang dihadapi oleh kesenian rakyat cukup berat. Karena pada era teknologi dan komunikasi yang sangat canggih dan modern ini masyarakat dihadapkan kepada banyaknya alternatif sebagai pilihan, baik dalam menentukan kualitas maupun selera. Hal ini sangat memungkinkan keberadaan dan eksistensi kesenian rakyat dapat dipandang dengan sebelah mata oleh masyarakat, jika dibandingkan dengan kesenian modern yang merupakan imbas dari budaya pop. Untuk menghadapi halhal tersebut di atas ada beberapa alternatif untuk mengatasinya, yaitu meningkatkan SDM bagi para seniman rakyat. Selain itu mengembalikan peran aparat pemerintah 
sebagai pengayom dan pelindung, dan bukan sebaliknya justru menghancurkannya demi kekuasaan dan pembangunan yang berorientasi pada dana-dana proyek atau dana-dana untuk pembangunan dalam bidang ekonomi saja.

Scholte melihat bahwa ada beberapa definisi yang dimaksudkan orang dengan globalisasi:

- Internasionalisasi: Globalisasi diartikan sebagai meningkatnya hubungan internasional. Dalam hal ini masing-masing negara tetap mempertahankan identitasnya masing-masing, namun menjadi semakin tergantung satu sama lain.

- Liberalisasi: Globalisasi juga diartikan dengan semakin diturunkan batas antar negara, misalnya hambatan tarif ekspor impor, lalu lintas devisa, maupun migrasi.

- Universalisasi: Globalisasi juga digambarkan sebagai semakin tersebarnya hal material maupun imaterial ke seluruh dunia. Pengalaman di satu lokalitas dapat menjadi pengalaman seluruh dunia.

- Westernisasi: Westernisasi adalah salah satu bentuk dari universalisasi dengan semakin menyebarnya pikiran dan budaya dari barat sehingga mengglobal.

- Hubungan transplanetari dan suprateritorialitas: Arti kelima ini berbeda dengan keempat definisi di atas. Pada empat definisi pertama, masing-masing negara masih mempertahankan status ontologinya. Pada pengertian yang kelima, dunia global memiliki status ontologi sendiri, bukan sekedar gabungan negara-negara.

\section{Ciri globalisasi:}

Berikut ini beberapa ciri yang menandakan semakin berkembangnya fenomena globalisasi di dunia. Hilir mudiknya kapal-kapal pengangkut barang antar negara menunjukkan keterkaitan antar manusia di seluruh dunia.

- Perubahan dalam konstantin ruang dan waktu. Perkembangan barangbarang seperti telepon genggam, televisi satelit, dan internet menunjukkan bahwa komunikasi global terjadi demikian cepatnya, sementara melalui pergerakan massa semacam turisme memungkinkan kita merasakan banyak hal dari budaya yang 
berbeda.

- Pasar dan produksi ekonomi di negara-negara yang berbeda menjadi saling bergantung sebagai akibat dari pertumbuhan perdagangan internasional, peningkatan pengaruh perusahaan multinasional, dan dominasi organisasi semacam World Trade Organization (WTO).

\section{- Peningkatan interaksi}

kultural melalui perkembangan media massa (terutama televisi, film, musik, dan transmisi berita dan olahraga internasional). Saat ini, kita dapat mengkonsumsi dan mengalami gagasan dan pengalaman baru mengenai halhal yang melintasi beraneka ragam budaya, misalnya dalam bidang fashion, literatur, dan makanan.

- Meningkatnya masalah bersama, misalnya pada bidang lingkungan hidup, krisis multinasional, inflasi regional dan lain-lain.

Kennedy dan Cohen menyimpulkan bahwa transformasi ini telah membawa kita pada globalisme, sebuah kesadaran dan pemahaman baru bahwa dunia adalah satu. Giddens menegaskan bahwa kebanyakan dari kita sadar bahwa sebenarnya diri kita turut ambil bagian dalam sebuah dunia yang harus berubah tanpa terkendali yang ditandai dengan selera dan rasa ketertarikan akan hal sama, perubahan dan ketidakpastian, serta kenyataan yang mungkin terjadi. Sejalan dengan itu, Peter Drucker menyebutkan globalisasi sebagai zaman transformasi sosial.

\section{Teori globalisasi}

Chocrane dan Pain menegaskan bahwa dalam kaitannya dengan globalisasi, terdapat tiga posisi teoritis yang dapat dilihat, yaitu:

- Para globalis percaya bahwa globalisasi adalah sebuah kenyataan yang memiliki konsekuensi nyata terhadap bagaimana orang dan lembaga di seluruh dunia berjalan. Mereka percaya bahwa negara-negara dan kebudayaan lokal akan hilang diterpa kebudayaan dan ekonomi global yang homogen. Meskipun demikian, para globalis tidak memiliki pendapat sama mengenai konsekuensi terhadap proses 
tersebut.

- Para globalis positif dan optimis menanggapi dengan baik perkembangan semacam itu dan menyatakan bahwa globalisasi akan menghasilkan mesyarakat dunia yang toleran dan bertanggung jawab.

- Para globalis pesimis berpendapat bahwa glonalisasi adalah sebuah fenomena negatif karena hal tersebut sebenarnya adalah bentuk penjajahan barat (terutama Amerika Serikat) yang memaksa sejumlah bentuk budaya dan konsumsi yang homogen dan terlihat sebagai sesuatu yang benar dipermukaan. Beberapa dari mereka kemudian membentuk kelompok untuk menentang globalisasi (anti globalisasi).

- Para tradisionalis tidak percaya bahwa globalisasi tengah terjadi. Mereka berpendapat bahwa fenomena ini adalah sebuah mitos semata atau, jika memang ada, terlalu dibesar-besarkan. Mereka merujuk bahwa kapitalisme telah menjadi sebuah fenomena internasional selama ratusan tahun. Apa yang tengah kita alami saat ini hanyalah merupakan tahap lanjutan, atau evolusi, dari produksi dan perdagangan kapital.

- Para transformasionalis berada di antara para globalis dan tradisionalis. Mereka setuju bahwa pengaruh globalisasi telah sangat dilebih-lebihkan oleh para globalis. Namun, mereka juga berpendapat bahwa sangat bodoh jika kita menyangkal keberadaan konsep ini. Posisi teoritis ini berpendapat bahwa globalisasi seharusnya dipahami sebagai "seperangkat hubungan yang saling berkaitan dengan murni melalui sebuah kekuatan, yang sebagian besar tidak terjadi secara langsung". Mereka menyatakan bahwa proses ini bisa dibalik, terutama ketika hal tersebut negatif atau, setidaknya, dapat dikendalikan.

\section{Sejarah globalisasi}

Banyak sejarahwan yang menyebut globalisasi sebagai fenomena di abad ke-20 ini yang dihubungkan dengan bangkitnya ekonomi internasional. Padahal interaksi dan globalisasi dalam hubungan antar bangsa di dunia telah ada sejak berabad-abad yang lalu. Bila ditelusuri, benih-benih globalisasi telah tumbuh 
ketika manusia mulai mengenal perdagangan antar negeri sekitar tahun 1000 dan 1500 M. Saat itu, para pedagang dari Tiongkok dan India mulai menelusuri negeri lain baik melalui jalan darat (seperti misalnya jalur sutera) maupun jalan laut untuk berdagang. Fenomena berkembangnya perusahaan McDonalds di seluruh pelosok dunia menunjukkan telah terjadinya globalisasi.

Fase selanjutnya ditandai dengan donimasi perdagangan kaum muslim di Asia dan Afrika. Kaum muslim membentuk jaringan perdagangan yang antara lain meliputi Jepang, Tiongkok, Vietnam, Indonesia, Malaka, India, Persia, pantai Afrika Timur, Laut Tengah, Venesia, dan Genoa. Di samping membentuk jaringan dagang, kaum pedagang muslim juga menyebarkan nilai-nilai agamanya, nama-nama, abjad, arsitek, nilai sosial budaya Arab ke warga dunia.

Fase selanjutnya ditandai dengan eksplorasi dunia secara besar-besaran oleh bangsa Eropa. Spanyol, Portugis, Inggris, dan Belanda adalah pelopor-pelopor eksplorasi ini. Hal ini di dukung pula dengan terjadinya revolusi industri yang meningkatkan keterkaitan antar bangsa dunia. Berbagai teknologi mulai ditemukan dan menjadi dasar perkembangan teknologi saat ini, seperti komputer dan internet. Pada saat itu, berkembang pula kolonialisasi di dunia yang membawa pengaruh besar terhadap difusi kebudayaan di dunia.

\section{Senakin berkembanganya} industri dan kebutuhan akan bahan baku serta pasar juga memunculkan berbagai perusahaan multinasional di dunia. Di Indonesia misalnya, sejak politik pintu terbuka, perusahaan-perusahaan Eropa membuka berbagai cabangnya di Indonesia. Freeport dan Exxon dari Amerika Serikat, Unilever dari Belanda, Brithis Petroleum dari Inggris adalah beberapa contohnya. Perusahaan multinasional seperti ini tetap menjadi ikon globalisasi hingga saat ini.

Fase selanjutnya terus berjalan dan mendapat momentumnya ketika perang dingin berakhir dan komunisme di dunia runtuh. Runtuhnya komunisme seakan memberi pembenaran bahwa kapitalisme adalah jalan terbaik dalam mewujudkan kesejahteraan dunia. Implikasinya, negara-negara di dunia mulai menyiapkan diri sebagai pasar yang bebas. Hal ini didukung pula dengan perkembangan teknologi komunikasi dan transportasi. Alhasil, sekat-sekat antar negara pun mulai kabur. 


\section{Reaksi Masyarakat}

\section{"Gerakan pro-globalisasi'}

Pendukung globalisasi (sering juga disebut dengan pro-globalisasi) menganggap bahwa globalisasi dapat meningkatkan kesejahteraan dan kemakmuran ekonomi masyarakat dunia. Mereka berpijak pada teori keunggulan komparatif yang dicetuskan oleh David Ricardo. Teori ini menyatakan bahwa suatu negara dengan negara lain saling bergantung dan dapat saling menguntungkan satu sama lainnya, dan salah satu bentuknya adalah ketergantungan dalam bidang ekonomi. Kedua negara dapat melakukan transaksi pertukaran sesuai dengan keunggulan komparatif yang dimilikinya. Misalnya, Jepang memiliki keunggulan komparatif pada produk kamera digital (mampu mencetak lebih efesien dan bermutu tinggi) sementara Indonesia memiliki keunggulan komparatif pada produk lainnya. Dengan teori ini jepang dianjurkan untuk menghentikan produksi kainnya dan mengalihkan faktor-faktor produksinya untuk memaksimalkan produksi kamera digital, lalu menutupi kekurangan penawaran kain dengan membelinya dari Indonesia, begitu juga sebaliknya.
Salah satu penghambat utama terjadinya kerjasama diatas adalah adanya larangan-larangan dan kebijakan proteksi dari pemerintah suatu negara. Di satu sisi, kebijakan ini dapat melindungi produksi dalam negeri, namun disisi lain, hal ini akan meningkatkan biaya produksi barang impor sehingga sulit menembus pasar negara yang dituju. Para proglobalisme tidak setuju akan adanya proteksi dan larangan tersebut, mereka menginginkan dilakukannya kebijakan perdagangan bebas sehingga harga barang-barang dapat ditekan, akibatnya permintaan akan meningkat. Karena permintaan meningkat, kemakmuran akan meningkat dan begitu seterusnya.

Beberapa kelompok proglobalisme juga mengkritik Bank Dunia dan IMF, mereka berpendapat bahwa dua badan tersebut hanya mengontrol dan mengalirkan dana kepada suatu negara, bukan kepada suatu koperasi atau perusahaan. Sebagai hasilnya, banyak pinjaman yang mereka berikan jatuh ke tangan para diktator yang kemudian menyelewengkan dan tidak menggunakan dana tersebut sebagaimana mestinya, meninggalkan rakyatnya dalam lilitan hutang negara, dan sebagai akibatnya, tingkat kemakmuran akan menurun. Karena tingkat kemakmuran menurun, 
akibatnya masyarakat negara itu terpaksa mengurangi tingkat konsumsinya termasuk konsumsi barang impor, sehingga laju globalisasi akan terhambat dan menurut mereka mengurangi tingkat kesejahteraan penduduk dunia.

\section{"Gerakan antiglobalisasi"}

Antiglobalisasi adalah suatu istilah yang umu digunakan untuk memaparkan sikap politis orang-orang dan kelompok yang menentang perjanjian dagang global dan lembaga-lembaga yang mengatur perdagangan antar negara seperti Organisasi Perdagangan Dunia (WTO).

"Antiglobalisasi" dianggap oleh sebagian orang sebagai gerakan sosial, sementara yang lainnya menganggapnya sebagai istilah umum yang mencakup sejumlah gerakan sosial yang berbedabeda. Apapun juga maksudnya, para peserta dipersatukan dalam perlawanan terhadap ekonomi dan sistem perdagangan global saat ini, yang menurut mereka mengikis lingkungan hidup, hak-hak buruh, kedaulatan nasional, dunia ketiga, dan banyak lagi penyebab-penyebab lainnya.

Namun, orang yang dicap “antiglobalisasi" sering menolak istilah itu, dan mereka lebih suka menyebut diri mereka sebagai Gerakan Keadilan Global, Gerakan dari Semua Gerakan atau sejumlah istilah lainnya.

Globalisasi perekonomian merupakan suatu proses kegiatan ekonomi dan perdagangan, dimana negara-negara di seluruh dunia menjadi satu kekuatan pasar yang semakin terintegrasi dengan tanpa rintangan batas teritorial negara. Globalisasi perekonomian mengharuskan penghapusan seluruh batasan dan hambatan terhadap arus modal, barang dan jasa.

Ketika globalisasi ekonomi terjadi, batas-batas suatu negara akan menjadi kabur dan keterkaitan antara ekonomi nasional dengan perekonomian internasional akan semakin erat. Globalisasi perekonomian di satu pihak akan membuka peluang pasar produk dari dalam negeri ke pasar internasional secara kompetitif, sebaliknya juga membuka peluang masuknya produk-produk global ke dalam pasar domestik. Menurut Tanri Abeng, perwujudan nyata dari globalisasi ekonomi antara lain terjadi dalam bentukbentuk berikut:

- Globalisasi produksi, di mana perusahaan berproduksi di berbagai negara, dengan sasaran agar biaya produksi menjadi lebih rendah. Hal 
ini dilakukan baik karena upah buruh yang rendah, tarif bea masuk yang murah, infrastruktur yang memadai atau pun karena iklim usaha dan politik yang kondusif. Dunia dalam hal ini menjadi lokasi manufaktur global.

- Globalisasi pembiayaan, perusahaan global mempunyai akses untuk memperoleh pinjaman atau melakukan investasi di semua negara di dunia. Sebagai contoh, PT Telkom dalam memperbanyak satuan sambungan telepon, atau PT Jasa Marga dalam memperluas jarinagn jalan tol telah memanfaatkan sistem pembiayaan dengan pola BOT (build operate transfer) bersama mitra usaha dari manca negara.

- Globalisasai tenaga kerja, perusahaan global akan mampu memanfaatkan tenaga kerja dari seluruh dunia sesuai kelasnya, seperti penggunaan staf profesional diambil dari tenaga kerja yang telah memiliki pengalaman internasional atau buruh kasar yang biasa diperoleh dari negara berkembang. Dengan globalisasi maka human movement akan semakin mudah dan bebas.

- Globalisasi jaringan informasi, masyarakat suatu negara dengan mudah dan cepat mendapatkan informasi dari negara-negara di dunia karena kemajuan teknologi, semakin maju telah membantu meluasnya pasar ke berbagai belahan dunia untuk barang yang sama. Sebagai contoh: KFC, Levi's, atau hamburger melanda pasar dimana-mana. Akibatnya selera masyarakat dunia menuju pada selera global.

- Globalisasi perdagangan, hal ini terwujud dalam bentuk penurunan dan penyeragaman tarif serta penghapusan berbagai hambatan nontarif. Dengan demikian kegiatan perdagangan dan persaingan menjadi semakin cepat, ketat, dan fair.

Thompson mencatat bahwa kaum globalis mengklaim saat ini telah terjadi sebuah intensifikasi secara cepat dalam investasi dan perdagangan internasional. Misalnya, secara nyata perekonomian nasional telah menjadi bagian dari perekonomian global yang ditengarai dengan adanya kekuatan pasar dunia. 


\section{Kebaikan Globalisasi Ekonomi}

\section{Produksi global dapat ditingkatkan}

Pandangan ini sesuai dengan teori 'keuntungan komparatif' dari David Ricardo. Melalui spesialisasi dan perdagangan faktor-faktor produksi dunia dapat digunakan dengan lebih efisien, output dunia bertambah dan masyarakat akan memperoleh keuntungan dari spesialisasi dan perdagangan dalam bentuk pendapatan yang meningkat, yang selanjutnya dapat meningkatkan pembelanjaan dan tabungan.

\section{Menigkatkan kemakmuran masyarakat} dalam suatu negara

Perdagangan yang lebih bebas memungkinkan masyarakat dari berbagai negara mengimpor lebih banyak barang dari luar negeri. Hal ini menyebabkan konsumen mempunyai pilihan barang yang lebih banyak. Selain itu, konsumen juga dapat menikmati barang yang lebih baik dengan harga yang lebih rendah.

\section{Meluasnya pasar untuk produk dalam negeri}

Perdagangan luar negeri yang lebih bebas memungkinkan setiap negara memperoleh pasar yang jauh lebih luas dari pasar dalam negeri.

\section{Dapat memperoleh lebih banyak modal dan teknologi yang lebih baik}

Modal dapat diperoleh dari investasi asing dan terutama dinikmati oleh negara-negara berkembang karena masalah kekurangan modal dan tenaga ahli serta tenaga terdidik yang berpengalaman kebanyakan dihadapi oleh negara-negara berkembang.

\section{Menyediakan dana tambahan untuk pembangunan ekonomi}

Pembangunan sektor industri dan berbagai sektor lainnya bukan saja dikembangkan oleh perusahaan asing, tetapi terutamanya melalui investasi yang dilakukan oleh perusahaan swasta domestik. Perusahaan domestik ini seringkali memerlukan modal dari bank atau pasar saham. Dana dari luar negeri teritama dari negara-negara maju yang memasuki pasar uang dan pasar modal di dalam negeri dapat membantu menyediakan modal yang dibutuhkan tersebut.

\section{Menghambat pertumbuhan sektor industri}

Salah satu efek dari globalisasi adalah perkembangan sistem perdagangan 
luar negeri yang lebih bebas. Perkembangan ini menyebabkan negaranegara berkembang tidak dapat lagi menggunakan tarif yang tinggi untuk memberikan proteksi kepada industri yang baru berkembang (infant industry). Dengan demikian, perdagangan luar negeri yang lebih bebas menimbulkan hambatan kepada negara berkembang untuk memajukan sektor industri domestik yang lebih cepat. Selain itu, ketergantungan kepada industri-industri yang dimiliki perusahaan multinasional semakin meningkat.

\section{Memperburuk neraca pembayaran}

Globalisasi cenderung menaikkan barang-barang impor. Sebaliknya, apabila suatu negara tidak mampu bersaing, maka ekspor tidak berkembang. Keadaan ini dapat memperburuk kondisi neraca pembayaran. Efek buruk lain dari globalisasi terhadap neraca pembayaran adalah pembayaran neto pendapatan faktor produksi dari luar negeri cenderung mengalami defisit. Investasi asing yang bertambah banyak menyebabkan aliran pembayaran keuntungan (pendapatan) investasi ke luar negeri semakin meningkat. Tidak berkembangnya ekspor dapat berakibat buruk terhadap neraca pembayaran.

\section{Sektor keuangan semakin tidak stabil}

Salah satu efek penting dari globalisasi adalah pengaliran investasi (modal) portofolio yang semakin besar. Investasi ini terutama meliputi partisipasi dana luar negeri ke pasar saham. Ketika pasar saham sedang meningkat, dana ini akan mengalir masuk, neraca pembayaran bertambah baik dan nilai uang akan bertambah baik. Sebaliknya, ketika harga saham dipasar saham menurun, dana dalam negeri akan mengalir ke luar negeri, neraca pembayaran cenderung menjadi bertambah buruk dan nilai mata uang domestik merosot. Ketidakstabilan di sektor keuangan ini dapat menimbulkan efek buruk kepada kestabilan kegiatan ekonomi secara keseluruhan.

\section{Memperburuk prospek pertumbuhan ekonomi jangka panjang}

Apabila hal-hal yang dinyatakan di atas berlaku dalam suatu negara, maka dalam jangka pendek pertumbuhan ekonominya menjadi tidak stabil. Dalam jangka panjang pertumbuhan yang seperti ini akan mengurangi lajunya pertumbuhan ekonomi. Pendapatan nasional dan kesempatan kerja akan semakin lambat pertumbuhannya dan masalah pengangguran tidak dapat diatasi atau malah semakin memburuk. Pada akhirnya, 
apabila globalisasi menimbulkan efek buruk kepada prospek pertumbuhan ekonomi jangka panjang suatu negara, distribusi pendapatan menjadi semakin tidak adil dan masalah sosial-ekonomi masyarakat semakin bertambah buruk.

\begin{tabular}{lll} 
& Globalisasi & \multicolumn{2}{c}{ mempengaruhi } \\
hampir semua aspek yang ada di
\end{tabular}
masyarakat, termasuk diantaranya aspek budaya. Kebudayaan dapat diartikan sebagai nilai-nilai (values) yang dianut oleh masyarakat ataupun persepsi yang dimiliki oleh warga masyarakat terhadap berbagai hal. Baik nilai-nilai maupun persepsi berkaitan dengan aspek-aspek kejiwaan/psikologis, yaitu apa yang terdapat dalam alam pikiran. Aspek-aspek kejiwaan ini menjadi penting artinya apabila disedari, bahwa tingkah laku seseorang sangat dipengaruhi oleh apa yang ada dalam alam pikiran orang yang bersangkutan. Sebagai salah satu hasil pemikiran dan penemuan seseorang adalah kesenian, yang merupakan subsistem dari kebudayaan.

Globalisasi sebagai sebuah gejala tersebarnya nilai-nilai dan budaya tertentu keseluruhan dunia telah terlihat sejak lama. Cikal bakal dari persebaran budaya dunia ini dapat ditelusuri dari perjalanan para penjelajah Eropa Barat ke berbagai tempat di sunia ini (Lucian W. Pye, 1966).

Namun, perkembangan globalisasi kebudayaan secara intensif terjadi pada awal ke-20 dengan berkembangnya teknologi komunikasi. Kontak melalui media menggantikan kontak fisik sebagai sarana utama komunikasi antar bangsa. Perubahan tersebut menjadikan komunikasi antar bangsa lebih mudah dikalukan, hal ini menyebabkan semakin cepatnya perkembangan globalisasi kebudayaan.

\section{Ciri berkembangnya globalisasi}

\section{kebudayaan}

- Berkembangnya pertukaran kebudayaan internasional.

- Penyebaran prinsip multikebudayaan, dan kemudahan akses suatu individu terhadap kebudayaan lain diluar kebudayaannya.

- Berkembangnya turisme dan pariwisata.

- Semakin banyaknya imigrasi dari suatu negara ke negara lain.

- Berkembangnya mode yang berskala global, seperti pakaian, film, dll.

- Bertambah banyaknya event- 
event berskala global, seperti Piala Dunia FIFA.

\section{Globalisasi Perekonomian}

$$
\text { Globalisasi perekonomian }
$$

merupakan suatu proses kegiatan ekonomi dan perdagangan, dimana negara-negara di seluruh dunia menjadi satu kekuatan pasar yang semakin terintegrasi dengan tanpa rintangan batas teritorial negara. Globalisasi perekonomian mengharuskan penghapusan seluruh batasan dan hambatan terhadap arus modal, barang dan jsa.

Ketika globalisasi ekonomi terjadi, batas-batas suatu negara akan menjadi kabur dan keterkaitan antara ekonomi nasional dengan perekonomian internasional akan semakin erat. Globalisasi perekonomian di satu pihak akan membuka peluang pasar produk dari dalam negeri ke pasar internasional secara kompetitif, sebaliknya juga membuka peluang masuknya produk-produk global ke dalam pasar domestik.

Pengaruh Globalisasi Terhadap NilaiNilai Nasionalisme

- Globalisasi adalah suatu proses tatanan masyarakat yang mendunia dan tidak mengenal batas wilayah.

- Globalisasi pada hakikatnya adalah suatu proses dari gagasan yang dimunculkan, kemudian ditawarkan untuk diikuti oleh bangsa lain yang akhirnya sampai pada suatu titik kesepakatan bersama dan menjadi pedoman bersama bagi bangsabangsa diseluruh dunia. (Edison A. Jamli dkk. Kewarganegaraan. 2005)

Menurut pendapat Krisna (Pengaruh Globalisasi Terhadap Pluralisme Kebudayaan Manusia di Negara Berkembang. Internet. Publik jurnal. September 2005). Sebagai proses, globalisasi berlangsung melalui dua dimensi dalam interaksi antar bangsa, yaitu dimensi ruang dan waktu. Ruang makin dipersempit dan waktu makin dipersingkat dalam interaksi dan komunikasi pada skala dunia. Globalisasi berlangsung di semua bidang kehidupan seperti bidang ideologi, politik, ekonomi, sosial budaya, pertahanan keamanan dan lain-lain. Teknologi informasi dan komunikasi adalah faktor pendukung utama dalam globalisasi. Dewasa ini, perkembangan teknologi begitu cepat sehingga segala informasi dengan berbagai bentuk dan kepentingan 
dapat tersebar luas ke seluruh dunia. Oleh karena itu, globalisasi tidak dapat kita hindari kehadirannya.

Kehadiran globalisasi tentunya membawa pengaruh bagi kehidupan suatu negara termasuk Indonesia. Pengaruh tersebut meliputi dua sisi yaitu pengaruh positif dan pengaruh negatif. Pengaruh globalisasi di berbagai bidang kehidupan seperti kehidupan politik, ekonomi, ideologi, sosial budaya dan lain-lain akan mempengaruhi nilai-nilai nasionalisme terhadap bangsa.

\section{- Pengaruh positif globalisasi}

\section{terhadap nilai-nilai nasionalisme}

1. Dilihat dari globalisasi politik, pemerintahan dijalankan secara terbuka dan demokratis. Karena pemerintahan adalah bagian dari suatu negara, jika pemerintahan dijalankan secara jujur, bersih dan dinamis tentunya akan mendapat tanggapan positif dari rakyat. Tanggapan positif tersebut berupa rasa nasionalisme terhadap negara menjadi meningkat.

2. Dari aspek globalisasi ekonomi, terbukanya pasar internasional, meningkatkan kesempatan kerja dan meningkatkan devisa negara. Dengan adanya hal tersebut akan meningkatkan kehidupan ekonomi bangsa yang menunjang kehidupan nasional bangsa.

3. Dari globalisasi sosial budaya kita dapat meniru pola berpikitr yang baik seperti etos kerja yang tinggi dan disiplin dan iptek dari bangsa lain yang sudah maju untuk meningkatkan kemajuan bangsa yang pada akhirnya memajukan bangsa dan akan mempertebal rasa nasionalisme kita terhadap bangsa.

- Pengaruh negatif globalisasi terhadap nilai-nilai nasionalisme

1. Globalisasi mampu meyakinkan masyarakat Indonesia bahwa liberalisme dapat membawa kemajuan dan kemakmuran. Sehingga tidak menutup kemungkinan berubah arah dari ideologi Pancasila ke ideologi liberalisme. Jika hal tersebut terjadi akibatnya rasa nasionalisme bangsa akan hilang.

2. Dari globalisasi aspek ekonomi, 
hilangnya rasa cinta terhadap produk dalam negeri karena banyaknya produk luar negeri (seperti McDonalds, CocaCola, Pizza Hut, dll) membanjiri Indonesia. Dengan hilangnya rasa cinta terhadap produk dalam negeri menunjukkan gejala berkurangnya rasa nasionalisme masyarakat kita terhadap bangsa Indonesia.

3. Masyarakat kita khususnya anak muda banyak yang lupa akan identitas diri sebagai bangsa Indonesia, karena gaya hiduonya cenderung meniru budaya barat yang oleh masyarakat dunia dianggap sebagai kiblat.

4. Mengakibatkan adanya kesenjangan sosial yang tajam antara yang kaya dan miskin, karena adanya persaingan bebas dalam globalisasi ekonomi. Hal tersebut dapat menimbulkan pertentangan antara yang kaya dan miskin yang dapat mengganggu kehidupan nasional bangsa.

5. Munculnya sikap individualisme yang menimbulkan ketidak pedulian antar perilaku sesama warga. Dengan adanya individualisme maka orang tidak akan peduli dengan kehidupan bangsa.

Pengaruh-pengaruh diatas memang tidak secara langsung berpengaruh terhadap nasionalisme. Akan tetapi secara keseluruhan dapat menimbulkan rasa nasionalisme terhadap bangsa menjadi berkurang atau hilang. Sebab globalisasi mampu membuka cakrawala masyarakat secara global. Apa yang ada di luar negeri dianggap baik memberi aspirasi kepada masyarakat kita untuk diterapkan di negara kita. Jika terjadi maka akan menimbulkan dilematis. Bila dipenuhi belum tentu sesuai di Indonesia. Bila tidak dipenuhi akan dianggap tidak aspiratif dan dapat bertindak anarkis sehingga mengganggu stabilitas nasional, ketahanan nasional bahkan persatuan dan kesatuan bangsa.

- Pengaruh globalisasi terhadap nilai nasionalisme di kalangan generasi muda

Arus globalisasi begitu cepat merasuk ke dalam masyarakat terutama di kalangan muda. Pengaruh globalisasi terhadap anak muda juga begitu kuat. Pengaruh globalisasi tersebut telah membuat banyak anak muda kita kehilangan kepribadian diri sebagai bangsa 
Indonesia. Hal ini ditunjukkan dengan gejala-gejala yang muncul dalam kehidupan sehari-hari anak muda sekarang.

Dari cara berpakaian banyak remaja-remaja kita yang berdandan seperti selebritis yang cenderung ke budaya barat. Mereka menggunakan pakaian yang minim bahan yang memperlihatkan bagian tubuh yang seharusnya tidak kelihatan. Pada hal cara berpakaian tersebut jelas-jelas tidak sesuai dengan kebudayaan kita. Tak ketinggalan gaya rambut mereka dicat beraneka warna. Pendek kata orang lebih suka jika menjadi orang lain dengan cara menutupi identitasnya. Tidak banyak remaja yang mau melestarikan budaya bangsa dengan mengenakan pakaian yang sopan sesuai dengan kepribadian bangsa.

Teknologi internet merupakan teknologi yang memberikan informasi tanpa batas dan dapat diakses oleh siapa saja. Apalagi bagi anak muda internet sudah menjadi santapan mereka seharihari. Jika digunakan secara semestinya tentu kita memperoleh manfaat yang berguna. Tetapi jika tidak, ada lagi pegangan wajib kita yaitu handphone. Rasa sosial terhadap masyarakat menjadi tidak ada karena mereka lebih memilih sibuk dengan menggunakan handphone.
Dilihat dari sikap, banyak anak muda yang tingkah lakunya tidak kenal sopan santun dan cenderung cuek tidak ada rasa peduli terhadap lingkungan. Karena globalisasi menganut kebebasan dan keterbukaan sehingga mereka bertindak sesuka hati mereka. Contoh riilnya adanya geng motor anak muda yang melakukan tindak kekerasan yang mengganggu ketentraman dan kenyamanan masyarakat.

Jika pengaruh-pengaruh di atas dibiarkan, mau apa jadinya generasi muda tersebut? Moral generasi bangsa menjadi rusak, timbul tindakan anarkis antara golongan muda. Hubungan dengan nilai nasionalisme akan berkurang karena tidak ada rasa cinta terhadap budaya bangsa sendiri dan rasa peduli terhadap masyarakat. Padahal generasi muda adalah penerus masa depan bangsa. Apa akibatnya jika penerus bangsa tidak memiliki rasa nasionalisme?

Berdasarkan analisa dan uraian di atas pengaruh negatif globalisasi lebih banyak daripada pengaruh positifnya. Oleh karena itu, diperlukan langkah untuk mengantisipasi pengaruh negatif globalisasi terhadap nilai nasionalisme.

\begin{tabular}{ccc}
\multicolumn{1}{c}{ Antisipasi } & pengaruh & negatif \\
globalisasi & terhadap & nilai \\
nasionalisme & &
\end{tabular}


Langkah-langkah untuk mengantisipasi dampak nagatif globalisasi terhadap nilai-nilai nasionalisme antara lain yaitu:

1. Menumbuhkan semangat nasionalisme yang tangguh, misal semangat mencintai produk dalam negeri.

2. Menanamkan dan mengamalkan nilainilai Pancasila dengan sebaik-baiknya.

3. Menanamkan dan melaksanakan ajaran agama dengan sebaik-baiknya.

4. Mewujudkan supremasi hukum, menerapkan dan menegakkan hukum dalam arti sebenar-benarnya dan seadil-adilnya.

5. Selektif terhadap pengaruh globalisasi di bidang politik, ideologi, ekonomi, sosial budaya bangsa.

Dengan adanya langkah-langkah antisipasi tersebut diharapkan mampu menangkis pengaruh globalisasi yang dapat mengubah nilai nasionalisme terhadap bangsa. Sehingga kita tidak akan kehilangan kepribadian bangsa.

\section{BAB IV}

\section{PENUTUP}

\section{A. KESIMPULAN}

Pengaruh globalisasi di satu sisi ternyata menimbulkan pengaruh yang negatif bagi kebudayaan bangsa Indonesia. Norma-norma yang terkandung dalam kebudayaan bangsa Indonesia perlahanlahan mulai pudar. Gencarnya serbuan teknologi disertai nilai-nilai interinsik yang diberlakukan di dalamnya, telah menimbulkan isu menginai globalisasi dan pada akhirnya menimbulkan nilai baru tentang kesatuan dunia. Radhakrishnan dalam bukunya Eastern Religion and Western Though (1924) menyatakan "untuk pertama kalinya dalam sejarah umat manusia, kesadaran akan kesatuan dunia telah menghentakkan kita, entah suka atau tidak, Timur dan Barat telah menyatu dan tidak pernah lagiterpisah" artinya adalah bahwa antara barat dan timur tidak ada lagi perbedaan. Atau dengan kata lain kebudayaan kita dilebur dengan kebudayaan asing. Apabila timur dan barat bersatu, masihkah ada ciri khas kebudayaan kita? Ataukah kita larut dalam budaya bangsa lain tanpa meninggalkan sedikitpun sistem nilai kita? Oleh karena itu, perlu dipertahankan aspek sosial budaya Indonesia sebagai identitas bangsa. Caranya adalah dengan penyaringan budaya yang masuk ke Indonesia dan pelestarian budaya bangsa. Bagi masyarakat yang mencoba mengembangkan seni tradisional menjadi 
bagian dari kehidupan modern, tentu akan terus berupaya memodifikasi bentukbentuk seni yang masih berpolakan masa lalu untuk dijadikan komoditi yang dapat dikonsumsi masyarakat modern. Karena sebarnya seni itu indah dan mahal. Kesenian adalah kekayaan bangsa Indonesia yang tidak ternilai harganya dan tidak dimiliki bangsa-bangsa asing. Oleh sebab itu, sebagai generasi muda, yang merupakan pewaris budaya bangsa, hendaknya memelihara seni budaya kita demi masa depan anak cucu.

\section{B. SARAN-SARAN}

Dari hasil pembahasan di atas, dapat dilakukan beberapa tindakan untuk mencegah terjadinya pergeseran kebudayaan yaitu: berbagai berita, hiburan dan informasi yang diberikan agar tidak menimbulkan pergeseran budaya.

- Masyarakat perlu menyeleksi kemunculan globalisasi kebudayaan baru, sehingga budaya yang masuk tidak merugikan dan berdampak negatif.

- Mesyarakat harus berhati-hati dalam meniru atau menerima kebudayaan baru, sehingga pengaruh globalisasi di negara kita tidak terlalu berpengaruh pada kebudayaan yang merupakan jati diri bangsa kita.

\section{DAFTAR PUSTAKA}

Adeney, Bernard T. 1995. Etika Sosial Lintas Budaya. Yogyakarta: Kanisius. Al-Hadar Smith,

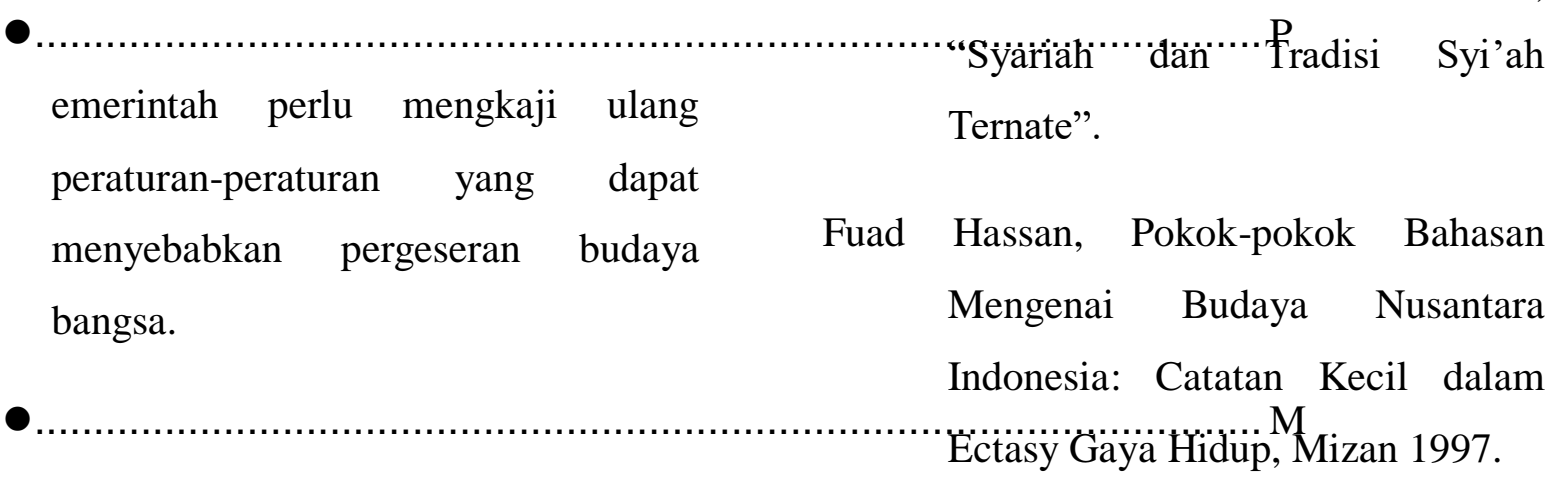
asyarakat perlu berperan aktif dalam pelestarian budaya daerah masingmasing khususnya dan budaya bangsa pada umumnya.

Koenjaraningrat. 1990. Kebudayaan Mentalitas dan Pembangunan. Jakarta: Gramedia.

Kuntowijoyo, Budaya Elite dan Budaya Massa dalam Ectasy Gaya Hidup: perlu mengadakan seleksi terhadap 
Kebudayaan Pop dalam Mutiara, Andalas. 1977. Pengaruh

Masyarakat Komoditas Indonesia, Mizan 1997.

Mahendra, Sucipta. 1990. Pengaruh Globalisasi Terhadap Nilai Nasionalisme di Kalangan Generasi Muda. Jakarta: Gramedia. Malcolm, Gladwell. 1990. Perubahan Budaya Dalam Globalisasi. Jakarta: Gramedia.
Globalisasi Terhadap Eksistensi Kebudayaan Daerah. Yogyakarta: Kanisius.

Sapardi Djoko Damono, Kebudayaan Massa dalam Kebudayaan Indonesia: Kebudayaan Pop dalam Masyarakat Komoditas Indonesia, Mizan 1997 